\title{
The Reliability of Foreign Language Anxiety Scale in Malay Version Based on Cronbach's Alpha
}

\author{
Rosnah Mohd Sham and Mohd Nazri Latiff Azmi \\ Faculty of Languages and Communication, \\ Universiti Sultan Zainal Abidin, Gong Badak Campus, \\ 21300 Kuala Nerus, Terengganu, Malaysia. \\ Email: rosnahmohdsham@gmail.com
}

\begin{abstract}
This paper is part of a study which addresses the reliability of Foreign Language Anxiety Scale (FLCAS) in Malay version. Researchers find that the reliability of an instrument is closely associated with its validity, and an instrument cannot be valid unless it is reliable. However, the reliability of an instrument does not depend on its validity. Therefore, this paper investigates the reliability of the instrument called FLCAS in Malay version. FLCAS is widely used in collecting data relating to language anxiety and perhaps the most reliable and comprehensive tool in language anxiety. This paper objectively measures the reliability of FLCAS by using Cronbach's Alpha, the most widely used objective measure of reliability. The sampled population involved 302 respondents from the government secondary schools in Putrajaya Federal Territory, Malaysia. The items had been translated into the Malay language and back translated into English. Results show that the internal consistency of Crobanch's Alpha 0.90. It can be concluded that FLCAS in Malay version is an appropriate instrument to measure the levels of language anxiety among the Malaysian secondary school students who learn English as a second language.
\end{abstract}

Keywords: reliability, FLCAS, Cronbach's Alpha, language anxiety.

\section{Introduction}

\subsection{Foreign Language Classroom Anxiety Scale (FLCAS)}

For the past three decades, studies in foreign and second language have been extensively used the Foreign Language Classroom Anxiety Scale (FLCAS) developed by (Horwitz, Horwitz \& Cope, 1986). FLCAS is an instrument used to investigate the levels of language anxiety in foreign and second language classroom anxiety. It is a widely used instrument in collecting data relating to language anxiety and perhaps the most reliable and comprehensive tool in language anxiety. It consists of 33 items in a 5-point Likert scale that range from "strongly agree" to "strongly disagree". The instrument 
consists of section A and B. In this paper, section A is designed to obtain respondents' demographic information including age, gender, race, name of school, and English test results. As for section B, 33 items are replicated, adapted and translated from Horwitz, Horwitz and Cope's (1991) FLCAS questionnaire. It measures communication apprehension, test anxiety and fear of negative evaluation. Cao (2011) was able to confirm three factor models of foreign language classroom anxiety scale (FLCAS) which is composed of three domains: communication, test anxiety, and fear of negative evaluation which are empirically derived through factor analysis and further confirmed having the best fit for language anxiety observation.

Horwitz, Horwitz and Cope's theory of foreign language anxiety has been widely accepted with subsequent research acknowledging the uniqueness of foreign language anxiety and providing evidence that the FLCAS is a reliable tool (Aling, 2016). FLCAS has been found out to be valid and reliable by Horwitz, Horwitz and Cope $(1986,1991)$.

However, perhaps it is not always possible to measure FLA levels by using FLCAS in English although English is a global language. This is due to several reasons namely cultural elements, leaners' English language proficiency levels, cross-cultural issues, differences in teaching and learning contexts (Aydin, 2016). Therefore, it is necessary to design a reliable and valid version of FLCAS in different languages (Aydin, 2016).

Thus, this paper has adapted and translated FLCAS into Malay version in order to measure language anxiety in the Malaysian context. Taking into account that this paper is conducted based on learning English as a second language, the term 'foreign language' in the questionnaires used in the original FLCAS has been replaced with 'English Language'. However, the name of FLCAS has not been changed. The translated FLCAS into Malay version has been validated by experts who has translated it into Malay version and translated it back into English version. This the first paper to publish the translated FLCAS into Malay version base on Cronbach's Alpha.

\subsection{Cronbach's Alpha}

Alpha was developed by Lee Cronbach (1951). Cronbach's alpha measures the reliability or internal consistency, of test items or set of scale (Sharma, 2016). In other words, the reliability of any given measurement refers to the extent to which it is a consistent measure of a concept. Reliability is defined as an internal consistency, which means the degree to which instrument measurement accurately, stability and repeatedly measure the proposed construct (Awang and Mohamad, 2015). In many reliability studies, heavy reliance on Cronbach's alpha ('the reliability coefficient') is widely used in business, nursing, social sciences and other disciplines. Cronbach's alpha generally increases when the inter-correlations among test items increase. This is known as an internal consistency estimate of reliability of test scores. The internal consistency of a scale or test is between 0 to 1 . Reliability estimates the amount of measurement error in a test by squaring the correlation and subtracting from 1.00 produces the index of measurement error. For example, in this paper a test has a reliability of 0.90 , there is 
0.19 error variance (random error) in the scores $(0.90 \times 0.90=0.81 ; 1.00-0.81=0.19)$. When the estimate of reliability increases, the fraction of a test score that is attributable to error decreases. Low value of Cronbach's alpha could be due the low correlations among pairs and consequently because of a low number of questions and hence some items may be deleted. If Cronbach's alpha is too high very close to one, then it may suggest that some items are redundant as they are testing the same question but in a different guise. It is recommended that 0.90 should be a maximum Cronbach's alpha value as illustrated in Table 1.

Table 1: Cronbach's Alpha Internal Consistency

\begin{tabular}{cl}
\hline Cronbach's Alpha & Internal Consistency \\
\hline$\alpha \geq 0.9$ & Excellent \\
$0.9>\alpha \geq 0.8$ & Good \\
$0.8>\alpha \geq 0.7$ & Acceptable \\
$0.7>\alpha \geq 0.6$ & Questionable \\
$0.6>\alpha \geq 0.5$ & Poor \\
$0.5>\alpha$ & Unacceptable \\
\hline
\end{tabular}

Source: Tavakol \& Dennick, 2011

It should be noted that an instrument cannot be valid unless it is reliable and the reliability of an instrument is closely associated with its validity (Tavakol \& Dennick, 2011). However, the reliability of an instrument does not depend on its validity.

\section{Literature Review}

FLCAS has been adapted, adopted and translated into a few languages such as Turkish, Croation, Arabic, Thai, Hungarian, Spanish and Japanese. In Turkey, Aydin (2016) had translated FLCAS into Turkish version by five independent Turkish translators. Result showed that the Turkish version seemed to have a higher level of reliability coefficient than the English version. Cronbach's Alpha for the Turkish version is 0.86 . The study recommended that the Turkish version of FLCAS is an appropriate instrument to measure the levels of foreign language anxiety among Turkish EFL learners (Aydin, 2016). Tepeh (2016) had conducted a study at a grammar school in South Croatia. She had adapted and translated FLCAS (1986) into Croation version. Result showed that the internal consistency of Croation version (FLCAS) is Cronbach's alpha 0.88. Al-Saraj (2014) had modified and translated FLCAS into Arabic version which is called Arabic Foreign Language Anxiety Questionnaire (AFLAQ). Result showed that the internal consistency of the AFLAQ is Cronbach's alpha 0.89. Yaikhong and Usaha (2012) developed a Public Speaking Class Anxiety Scale to measure EFL public speaking anxiety among the Thai students. Some of the items were adopted from FLCAS. Minor changes were made in some of the adopted items in the scale. The Cronbach's Alpa showed the value of 0.84 . Toth (2008) adapted FLCAS for the use of Hungarian EFL learners. It was translated to Hungarian language and back-translated to English language. The coefficient of the scale completed by 117 English majors turned out to be Cronbach's 
alpha 0.93 and 0.92 for 66 non-English majors. Cebreros (1998) had translated FLCAS into Spanish version. Result revealed that the internal consistency was Cronbach's alpha 0.8164. Aida (1994) adapted FLCAS in order to establish reliability and validity as a measuring tool of language anxiety for Japanese students. The internal consistency of FLCAS in Japanese is Cronbach's alpha 0.92.

Based on the previous studies FLCAS has shown its stability, homogeneity and equivalence. FLCAS obtains the same result in repeated administrations. The same tools have used more than once and it is shown how reliable the tool is when there is a reliability co-efficient every time it is tested. Researchers have agreed among them when the same data collection tool are compared and calculated a correlation coefficient (Twycross and Shields, 2004, p.36).

\section{Research Method}

This paper has adapted and translated FLCAS into Malay version in order to measure language anxiety in the Malaysian context. Taking into account that this study is conducted based on learning English as a second language, the term 'foreign language' in the questionnaires used in the original FLCAS has been replaced with 'English Language'. However, the name of FLCAS has not been changed. The translated FLCAS into Malay version has been validated by a few experts who have translated it into Malay version and translated it back into English version.

\subsection{Participants}

The participants in this paper were 302 of male and female students who have passed in the English subject in the mid-term examination 2017 from the government secondary schools, Putrajaya Federal Territory.

\subsection{Tools}

The data collecting tools consisted of participants' gender, age, school and ethnic. The Malay version consisted of 33 items with the same content and range as the original English version.

\subsection{Procedure}

The paper consisted of three main steps: Translation, administration and statistical analysis. First, the English version of FLCAS was translated into Malay language. Then, the Malay version was administered. Finally, a statistical analysis was carried out.

\subsubsection{Step 1: Translation}

This process has three phases. In the first phase, three translators were asked to translate the English version of FLAS to Malay version. All of them are English teachers who have experienced in teaching English as a second language for more than 10 years. One of them has taught English for more than 30 years and has graduated from one of the universities in the United Kingdom. All of them have Bachelor Degrees in "Teaching English as a second language" (TESL) and one of them has a Master in TESL. In the second 
phase, they brainstormed and compared the translated Malay versions until all of them had satisfied with it. In the third phase they translated back the Malay version to the English version. After they had discussed, compared and agreed with it then, they proceed with the agreed Malay version of FLCAS.

\subsubsection{Step 2: Administration}

The Malay version of FLAS was administered to the participants in October 2017. All of the copies were numbered accordingly. Participants were randomly selected from form four male and female students who had passed in the mid-term examination in 2017, from each government secondary school in Putrajaya Federal Territory. The number of students who had passed in the mid-term examination was also obtained from the schools and to be used as a sampling frame for this study. $30 \%$ of the participants were selected from the sampling frame.

Once the respondents had been identified, the English teachers proceeded to the classrooms during the time when the students were having their class session. The researcher was not allowed to go to the classrooms. The respondents answered the questionnaire at their convenient time after the English teachers had finished teaching. The study employed the above method in order to allow respondents to answer the questionnaires without any pressure so whatever response provided reflects the true opinion from the respondents. Therefore, the response bias due to the time constraint and the presence of researcher would not occur.

\subsubsection{Step 3: Statistical analysis}

The data collected were analysed using the SPSS descriptive analysis. The descriptive statistics are used to describe the basic features of data (Pallant, 2013). One of the most common measure of central tendency is mean, which is defined as the average value of the data set (Sekaran and Bougie, 2010). Then, the Conbach's Alpha was calculated.

\section{Results}

\subsection{Internal Consistency}

Values given in Table 2 show that the reliability level for FLCAS in Malay version is acceptable. Cronbach's Alpha for the original version is found to be 0.90 , whereas Cronbach's Alpha based on standardized items is 0.91 . The internal consistency is excellent. In this paper the Cronbach's Alpha value is 0.90 which is the same maximum value as recommended by Tavakol and Dennick (2011).

Table 2: Reliability Statistics.

\begin{tabular}{lll}
\hline Cronbach's Alpha & $\begin{array}{c}\text { Cronbach's Alpha Based } \\
\text { on Standardized Items }\end{array}$ & N of Items \\
\hline 0.90 & 0.91 & 33 \\
\hline
\end{tabular}




\subsection{Descriptive Analysis}

Table 3 highlights descriptive analysis which measures the level of language anxiety of form four students at the government secondary schools in Putrajaya Federal Territory.

An inspection of the mean scores indicated that the anxiety level of male students reported slightly higher in test anxiety and fear of negative evaluation than female students. The mean score of communication apprehension is reported that male and female students experience the same level. Table 3 illustrates the mean value of communication apprehension, test anxiety and fear of negative evaluation between male and female students. The mean value shows that both male and female students experienced low level of language anxiety.

Table 3: Mean Value between Male and Female Students.

\begin{tabular}{llll}
\hline GENDER & CA & TA & FNE \\
\hline Male & 1.77 & 1.72 & 1.81 \\
Female & 1.77 & 1.70 & 1.80 \\
\hline
\end{tabular}

\section{Discussion}

The main aim of this paper is to measure the reliability of FLCAS in Malay version. It also measures the level of language anxiety experienced by 302 form four students from the secondary schools in Putrajaya Federal Territory. Government secondary schools in Putrajaya Federal Territory have scored the highest number of students pass in English subject in Malaysia (Malaysia, Ministry of Education, 2017). This paper has taken the statistic from the Ministry from 2006 until 2017.

FLCAS has become the focus of many language learning research in language anxiety. Findings have shown different results. Based on the instrument, Horwitz, Horwitz and Cope (1986) proposed a three factor model namely communication apprehension, test anxiety and fear of negative evaluation. A large number of studies have been using it as the theoretical framework. Each researcher may have his or her own way of interpreting the data, which does not necessarily mean that way is right and the other ways are wrong. In addition, it is evident that since the introduction of FLCAS as an instrument to measure the anxiety levels, there is no clear cut relationship between the language anxiety and language performance. However, the reliability test has shown consistent results.

Alpha is an important concept in the evaluation of assessments and questionnaires. It is mandatory that assessors and researchers should estimate the reliability and accuracy to the interpretation of their data. 


\section{Conclusion}

This paper aims to proof that FLCAS (Horwitz, Horwitz\& Cope, 1986) in Malay version is a reliable tool to measure the language anxiety among the secondary school students in Malaysia. Cronbach's alpha is reporting the reliability of FLCAS accurately and scientifically. The main objective of reporting the reliability of FLCAS deals with the extent to which the instrument yields the same results on repeated trials.

\subsection{Implication of the Study}

This paper has demonstrated the statistical aspect of getting reliability of FLCAS in Malay version in measuring the language anxiety among the male and female students in the secondary schools in Malaysia. The statistical analysis used in this paper reported the reliability of FLCAS instrument with the Cronbach's Alpa 0.90. This paper will be helpful for researchers in language anxiety to investigate the language anxiety in Malay version. The validity of FLCAS will be written by the author in the next article.

\section{Acknowledgements}

Special appreciation to the Examinations Syndicate, Education Planning and Research Division, Ministry of Education Malaysia and all the government secondary schools in Putrajaya Federal Territory for their kind co-operations. This study would not have been possible without their co-operations.

\section{Appendix A: The Malay Version of Foreign Language Anxiety Scale}

Berikut adalah penyataan yang merujuk kepada perasaan yang anda rasakan atau tidak anda rasakan terhadap mempelajari dan berbual didalam Bahasa Inggeris. Baca setiap penyataan, kemudian pilih penyataan yang anda setuju dengan membulatkan nombor 1, atau 2, atau 3, atau 4, atau 5.

$\begin{array}{ccccc}\begin{array}{c}\text { Strongly Agree } \\ \text { (Sangatsetuju) }\end{array} & \begin{array}{c}\text { Agree } \\ \text { (Setuju) }\end{array} & \begin{array}{c}\text { Neutral } \\ \text { (Neutral) }\end{array} & \begin{array}{c}\text { Disagree } \\ \text { (Tidaksetuju) }\end{array} & \begin{array}{c}\text { Strong Disagree } \\ \text { (Sangattidaksetuju) }\end{array} \\ 5 & 4 & 3 & 2 & 1\end{array}$

1. Saya tidak pernah rasa yakin apabila bercakap di dalam bahasa Inggeris.

2. Saya sentiasa bimbang akan melakukan kesilapan ketika $\begin{array}{llllll}5 & 4 & 3 & 2 & 1\end{array}$ berada di dalamkelas Bahasa Inggeris.

3. Saya gementar apabila mengetahui bahawa saya akan di panggil ketika di dalam kelas Bahasa Inggeris.

4. Ianya menakutkan saya apabila saya tidak memahami apa yang dikatakan oleh guru Bahasa Inggeris.

5. lanya sangat mengganggu saya untuk menghadiribanyakkelas Bahasa Inggeris.

6. Semasa kelas Bahasa Inggeris, saya dapatidirisaya

\section{5}

4

3

21

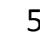

5

$\begin{array}{llll}4 & 3 & 2 & 1\end{array}$

$\begin{array}{llll}4 & 3 & 2 & 1\end{array}$

$\begin{array}{llll}4 & 3 & 2 & 1\end{array}$


memikirkan perkara-perkara yang tiada kena mengena dengan kursus yang sedang dijalankan.

7. Saya selalu berfikir bahawa pelajar-pelajar lain menguasai bahasa Inggeris lebih baik dari saya.

8. Biasanya saya tidak merasa selesa ketika mengambil ujian 5 Bahasa Inggeris.

9. Saya mula merasa panik apabila terpaksa bercakap 5 Bahasa Inggeris di dalam kelas tanpa membuat persediaan.

10. Saya risau dengan kemungkinan saya akan gagal dalam kelas Bahasa Inggeris.

11. Saya faham kenapa sesetengah orang merasa kecewa ketika menghadiri kelas Bahasa Inggeris.

\section{4}

\section{3}

4

3

4

3

2. Ketika kelas Bahasa Inggeris, saya merasa begitu

3

2 gementar, sehingga kan saya lupa perkara-perkara yang saya tahu.

13. lanya sesuatu yang memalukan saya untuk menjawab soalan secara sukarela di dalam kelas Bahasa Inggeris.

14. Sayaakan rasa gementar apabila bercakap Bahasa Inggeris dengan penutur asli Bahasa Inggeris.

15. Saya merasa kecewa apabila saya tidak memahami pembetulan yang dibuat oleh guru Bahasa Inggeris saya.

16. Walaupun saya bersedia untuk kelas Bahasa Inggeris namun saya tetap merasa cemas untuk menghadapinya.

17. Saya selalu merasakan untuk tidak menghadiri kelas Bahasa Inggeris.

18. Saya tidak merasa yakin apabila bercakap Bahasa Inggeris di dalam kelas.

19. Saya bimbang guru bahasa Inggeris bersedia untuk membetulkan setiap kesilapan yang saya lakukan.

20. Saya merasakan jantung saya berdebar-debar apabila di panggil oleh guru bahasa Inggeris.

21. Semakin banyak saya belajar bahasa Inggeris untuk peperiksaan semakin saya menjadi keliru.

22. Saya merasa tertekan untuk membuat persediaan yang rapi untuk kelas bahasa Inggeris.

$\begin{array}{llll}4 & 3 & 2 & 1\end{array}$


The Reliability of Foreign Language Anxiety Scale in Malay Version Based on Cronbach's Alpha, Rosnah Mohd. Sham and Mohd Nazri Latiff Azmi

Bercakap bahasa Inggeris lebih baik dari saya.

24. Saya berasa sangat berhati-hati apabila bertutur di dalam 5 Bahasa Inggeris di hadapan pelajar-pelajar lain.

25. Kelas bahasa Inggeris berjalan begitu cepat jadi saya bimbang yang saya akan ketinggalan.

26. Saya merasa tegang dan gementar di dalam kelas bahasa Inggeris berbanding kelas-kelas lain.

27. Saya merasa gementar dan keliru apabila bertutur di dalam kelas bahasa Inggeris.

28. Ketika saya di dalam perjalanan kekelas bahasa Inggeris, saya berasa tidak pasti dan tidak tenang.

29. Saya gementar apabila tidak memahami setiap perkataan yang dikatakan oleh guru bahasa Inggeris.

30. Saya berasa terancam dengan bilangan peraturan yang saya perlu belajar untuk betutur di dalam bahasa Inggeris.

31. Saya bimbang pelajar-pelajar lain akan ketawakan saya apabila saya bertutur didalam bahasa Inggeris.

32. Saya mungkin akan berasa tidak selesa apabila dikelilingi 5 oleh penutur asli bahasa Inggeris.

33. Saya menjadi gementar apabila guru bahasa Inggeris bertanya kan soalan-soalan yang mana saya tidak membuat persediaan terlebih dahulu.

\section{References}

Abu-ghararah, A. (1998). Foreign language classroom anxiety scale. King Abdul-Aziz University Journal for Educational Sciences, 11, 287-321.

Aida, Y. (1994). Examination of Horwitz, Horwitz and Cope's construct of foreign language anxiety: The case of students of Japanese. The Modern Language Journal., 78,155-168.

Ali, M. (2010). Difficulties of learning English and its relation to learning styles of middle school first year students. Unpublished Master Thesis, College of Education, Minia University, Egypt.

Ali, M. (2016). Confirmatory Factor Analysis of English Language Learning Anxiety Scale (ELLAS) in the Egyptian Context. International Educational E-Journal., 5(2), 111.

Aling, C. (14-15 March 2016). A Study on ESL and EFL Students' Language Anxiety in a Native Speaking Environment. Paper presented at the 4th Globat Summit on Education GSE. Kuala Lumpur. 
Al-Saraj, T. (2014). Revisiting the foreign language classroom anxiety scale (FLCAS): The anxiety of female English language learners in Saudi Arabia. L2 Journal., 6(1), 50-76.

Awang, Z. \& Mohamad, M. (2015). Postgraduate Research Proposal: A Step by Step Guide in Writing Proposals for Postgraduate Students. Bandar Baru Bangi: MPWS Rich Publication.

Aydin, S., et. al. (2016). A Turkish Version of Foreign Language Anxiety Scale: Reliability and Validity. Procedia-Social and Behavioral Sciences. 232, 250-256.

Bora, K. \&. (2011). The validity of FLCAS base on Item Response Theory. Modern British and American Literature, 29(3), 21-40.

Cao, Y. (2011). Comparison of two models of foreign language classroom anxiety scale. Philippines ESL Journal, 7, 73-93.

Cebreros, A. M. (1998). Measuring Language Anxiety Perceived by Spanish University Students of English., Retrieved from http://www.raco.cat/index.php/ Bells/article/view.

Cheng, Y. (2004). A measure of second language anxiety: Scale development and preliminary validation. Journal of Second Language Writing, 13, 313-335.

Cronbach, L. J. (1994). Coefficient alpha and the internal structure of tests. Psychometrika, 16(3), 3291-3234.

Guntzviller, L. J. (2011). The Foreign Language Anxiety in a Medical Office Scale: Developing and validating a measurement tool for Spanish-speaking individuals. Journal of Health Communication, 16(8), 849-869.

Horwitz, E. K. (1991). Preliminary Evidence for the reliability and validity of a foreign language anxiety scale. In E. Horwitz \& D. Young (Eds.), Language anxiety: From theory and research to classroom implication, (pp. 141-150). Englewood Cliffs, NJ: Prentice Hall.

Horwitz, E. K. \& Young, D. J. (1991). Language anxiety: From Theory and Research to Classroom Implications. Eaglewood Cliffs, N. J.: Prentice Hall.

Horwitz, E. K., Horwitz, M. B. \& Cope, J. A. (1986). Foreign Language Classroom Anxiety. Modern Language Journal, 70, 125-132.

Kim, Y. (2002). Construction of a theoretical model of foreign language anxiety and development of abmeasure of the construct: Korean university EFL learners' case. Unpublished Doctoral Dissertation, Faculty of the University Graduate School, the School of Education, Indiana University, USA. Malaysia, Ministry of Education (2017).

$\mathrm{Na}$, Z. (2007). A Study of High School Students' English Learning Anxiety. Asian EFL Journal., 9(3), 22-23.

Nunnally, J. C. (1978). Psychometric theory (2nd ed.). New York, NY: McGraw-Hill.

Sekaran, U. \& Bougie, R. (2010). Research Methods for Business (5th Ed.). West Sussex, United Kingdom: John Wiley \& Sons Ltd.

Sharma, B. (2016). A focus on reliability in developmental research through Cronbach's Alpha among medical, dental and paramedical professionals. Asian Pac. J. Health Sci.,, 3(4), 271-278.

Tavakol, M. \& Dennick, R. (2011). Making sense of Cronbach's alpha. International Journal of Medical Education, 2, 53-55. 
Thatcher, R. (2010). Validity and reliability of quantitative electroencephalography (EEG). Journal of Neurotherapy , 14, 122-152.

Toth, Z. (2008). A foreign language anxiety scale for Hungarian learners of English. Working Papers in Language Pedagogy, 2, 55-78.

Twycross, A. \& Shields, L. (2004). Validity and Reliability - What's it all about? Part 2 Reliability in quantitative studies. Paediatric Nursing., 16(10), 36.

Yaikhong, K. \& Usaha, S. (2012). A Measure of EFL Public Speaking Class Anxiety: Scale Development and Preliminary Validation and Reliability. English Language Teaching, 5(12), 23-35. 